\title{
Surviving Difference: Endocrine-Disrupting Chemicals, Intergenerational Justice, and the Future of Human Reproduction
}

Robyn Lee

Roxanne Mykitiuk

Osgoode Hall Law School of York University, rmykitiuk@osgoode.yorku.ca

Source Publication:

Feminist Theory 19:2 (2018) pp. 205-221

Follow this and additional works at: https://digitalcommons.osgoode.yorku.ca/scholarly_works

Part of the Endocrinology, Diabetes, and Metabolism Commons, and the Law Commons

\section{Recommended Citation}

Lee, Robyn and Roxanne Mykitiuk. "Surviving Difference: Endocrine-Disrupting Chemicals, Intergenerational Justice, and the Future of Reproduction." Feminist Theory. Forthcoming.

This Article is brought to you for free and open access by the Faculty Scholarship at Osgoode Digital Commons. It has been accepted for inclusion in Articles \& Book Chapters by an authorized administrator of Osgoode Digital Commons. 


\title{
Surviving Difference: Endocrine-Disrupting Chemicals, Intergenerational Justice, and the Future of Human Reproduction
}

\author{
Robyn Lee and Roxanne Mykitiuk
}

Supported by grant RHF100625 and grant RHF 100626 from the Institute for Human Development, Child and Youth Health (IHDCYH), Canadian Institutes of Health Research (CIHR)

Of the host of environmental threats to our health, endocrine-disruption has been highlighted as interfering with human sexuality and reproduction and as posing a threat to the future of our survival as a species (Casals-Casas and Desvergne, 2011). An endocrine disruptor is a chemical with the potential to alter hormone action within the body resulting in developmental and reproductive anomalies. Endocrine-disrupting chemicals have potentially lifelong and intergenerational effects on human reproduction and development (Zoeller et al., 2012; Vandenberg et al., 2012). These chemicals may negatively impact the fertility of future generations, and the changes they produce may be epigenetic; that is, they may be passed on to future generations (Rissman and Adli, 2014).

The question of justice for future generations has received extensive attention by philosophers, economists, and legal scholars, but has largely drawn on the liberal tradition of rights and individual autonomy. Feminist approaches to intergenerational justice have critiqued liberal conceptions of autonomy and drawn on ethics of care in 
order to ground human rights claims in relationality. However, the key feminist insight of the importance of intersectionality has been missing from the majority of treatments of intergenerational justice. Discussions of intergenerational justice need to recognize the politics of gender, race, poverty, and sexuality, all of which are conspicuously absent from the dominant debates over intergenerational justice. As Iris Marion Young argued, a concept of justice needs to focus on the elimination of institutionalized oppression, particularly of those who represent "difference" (Young, 2011).

As a consequence of endocrine disruptors' effects on human sexuality and reproduction, responses to the threats they pose frequently rely on a medicalized understanding of the body and normative gender identity. However, as (Scott, 2009) argues, harm should be identified in terms of illness and suffering, not in terms of difference. The challenges to normative ideals of bodies and gender by feminists, queer theorists, and critical disability scholars and activists must be included in an ethical response to the intergenerational threats posed by endocrine disruptors while resisting normative ideals of bodies and health.

This paper develops a feminist framework of intergenerational justice in response to the potential risks posed by endocrine-disrupting chemicals. We examine critiques of endocrine-disruptors from feminist, critical disability, and queer standpoints, and explore issues of race and class in exposures. We argue that responding to the threat posed by endocrine-disruptors like BFRs and phthalates requires developing a theory of intergenerational justice that recognizes relationality and transcorporeality - that our bodies and environments are porous: our bodies interact not only with each other, but 
also with non-human creatures and physical landscapes (Alaimo, 2010a) - as well as the effects of interlocking systems of oppression.

We explore ethical models by Irigaray, Arendt, and Levinas that promote responsibility to future generations while remaining open and responsive to the difference they represent, since in theorizing the requirement to protect future generations from harm we must not foreclose on the differences of those future generations. We develop a feminist understanding of genealogy, and, following Elizabeth Grosz, we argue that theorizing an intergenerational justice response to endocrine disruptors requires going beyond an understanding of difference as the basis of medicalized harms, to a positive theory of becoming.

\section{Endocrine disrupting chemicals and their effects}

A wide range of substances are thought to cause endocrine disruption, including pharmaceuticals, dioxin and dioxin-like compounds, polychlorinated biphenyls, DDT and other pesticides, and plasticizers such as Bisphenol A. Two types of endocrine-disrupting chemicals that we are exposed to through everyday life have recently become subjects of broad concern for scientists, regulators, environmental NGOs, and have featured prominently in media coverage: brominated flame retardants (BFRs) and phthalates. Phthalates are used to make plastics soft and malleable and are found in food packaging and water bottles, but also in car interiors, plumbing, cosmetics and personal care products (Halden, 2010; Wittassek, 2008). Many products that are scented contain phthalates, since they are used as solubulizers (an agent that something is dissolved in). Brominated flame retardants (BFRs) are intentionally added to products to reduce the risk 
of fire, and are found in fabrics, furniture foam, carpets and electronics, throughout our homes, workplaces, public transit, hospitals, libraries, and schools. Because of widespread environmental contamination, house dust and the food supply are also major sources of exposure to BFRs and phthalates (Schecter et al., 2010; Stapleton et al., 2012; Serrano et al., 2014).

BFRs and phthalates have been linked to intergenerational effects, although the impacts are still largely uncertain (Perera and Herbstman, 2011; Rider, 2010; Albert and Jégou, 2013). Clinical studies indicate that BFRs are impacting early stages of human development and can result in reproductive anomalies, including preterm births and spontaneous abortions (Morales-Suárez-Varela et al., 2011; Peltier et al., 2015; Small et al., 2011). Phthalates negatively impact human reproduction: they are associated with reduced semen quality, endometriosis, and shorter gestation periods during pregnancy (Sharpe and Irvine, 2004; Weuve et al., 2010). Phthalates have been linked to both prenatal and postnatal effect, including abnormal development of the male reproductive system (Rider, 2010; Martino-Andrade, 2009; Lottrup, 2006), with potentially irreversible anti-androgenic effects in fetuses (Kortenkamp, 2010; Albert and Jégou, 2013). Early menopause resulting from exposure to certain phthalates has also been indicated (Grindler et al., 2015). Assessing the risks from endocrine disruptors is complicated by variance in dose responses, differing vulnerabilities depending on when the age of exposure, and the complexity of chemical interactions in our environment (Casals-Casas and Desvergne, 2011).

\section{Intergenerational justice and anti-oppressive politics}


Iris Marion Young argues that a concept of justice needs to focus on the elimination of institutionalized oppression, particularly of those who represent "difference" (Young, 2011). Conceptions of intergenerational justice often founder on the question of future persons. Similarly, a concept of intergenerational justice needs to account for the politics of gender, race, and poverty. Intragenerational justice (between the members of a given generation) and intergenerational justice (between different generations) must be understood as necessarily connected, since potential harms to present and future generations from BFRs and phthalates may be unequally distributed according to factors such as socioeconomic status, race, and sex (Zota, Adamkiewicz, and Morello-Frosch, 2010; Wolff et al., 2007; Trasande et al., 2013).

While "environmental equity" can imply the equal sharing of risk burdens, rather than a reduction of the risks overall, "environmental justice" is a more politically charged term referring to remedial action taken to correct injustices imposed on a specific group of people, primarily people of colour (Cutter, 2012). The environmental justice movement has exposed the disparities of chemical exposures, with marginalized people usually being more at risk of negative health effects from exposures (Cole and Foster, 2001). However, Guthman and Mansfield (2012) note that the environmental justice movement has largely treated environments as inert places, separate from bodies. For example, the intergenerational impact of endocrine-disrupting chemicals can be significantly greater on some aboriginal communities than other communities because they live in the same place for generations (Scott, 2010). Aboriginal communities often contain higher levels of environmental contamination as a consequence of histories of colonialism, and must contend with contamination of traditional foods such as game and 
fish along with food insecurity as a consequence of poverty (Hlimi et al., 2012).

Environmental justice and reproductive justice struggles converge for many aboriginal communities (Hoover et al., 2012).

Recognizing our transcorporeality casts doubt on our ability to manage and control risk, implicitly understood as "outside", because in fact bodies and environments are porous (Alaimo, 2010b). Research is showing that effects from toxic exposures may depend on multiple factors such as malnutrition and stress (Gee and Payne-Sturges, 2004). Exposures to these endocrine disrupting chemicals are ubiquitous and given the current absence of regulation, exposures to them is difficult, bordering on impossible, to avoid. Socioeconomic status is a variable in exposures to these chemicals, although for some endocrine disruptors, higher income is actually associated with higher exposures (Tyrrell et al., 2013), and eating organic food in an effort to reduce exposures appears, at least in one recent study, to actually increase exposure (Sathyanarayana et al., 2013).

Although awareness of intergenerational effects might risk increasing perceived maternal responsibility for the health of children, because it has been widely concluded that race and socioeconomic status have enormous impacts on the health of populations, individuals may have far less control over their own health or the health of their children (Hessler, 2013). This leads Hessler (2013) to argue that from a health perspective it is important to promote justice in our society, especially given that oppression can have transgenerational effects.

In assessing the potential risks from BFRs and phthalates we must ask whose reproduction is currently valued and whose is not in our society; this means we must take systems of oppression into account. As the reproductive justice movement has pointed 
out, systems of oppression have often drastically restricted reproductive choices for racialized women (Nelson, 2003). Intersectionality demands that we consider the insights of both the environmental justice and the reproductive justice movements.

Endocrine-disruptors have garnered widespread attention and concern due to the changes they can produce in human sexual appearance and reproductive processes and function. However, the ways in which the threats from endocrine-disruptors have been framed are problematic from a feminist perspective because they frame mothers as the primary mediators of threats, and they rely on binary, regimented understandings of sexual difference.

As a result of the ubiquity of chemical exposures, the maternal body has been popularly conceived as contaminated and a threat to the fetus (Anstey, 2009). The ideal of the "good mother" requires women to preserve the purity of their children against the threats posed by environmental contamination (Cairns, 2013). Feminists have pointed out that women are disproportionately blamed for harms to children, with little to no corresponding attention paid to the effects of men's reproductive capacities on the health of children (Sheldon, 1999; Daniels, 2006). Mothers bear a disproportionate responsibility for managing their children's health, and are held disproportionately responsible for any perceived "imperfections" in their children's physical and mental health (Kukla, 2008).

Future illnesses caused by exposure to BFRs and phthalates will require care, which is likely to be predominantly carried out by women (Sze, 2007). In the case of negative impacts on reproduction, women are more likely to be subject to medical interventions in the form of reproductive technologies, and their outcomes will vary 
dramatically as a result of socioeconomic and racial disparities (Birke, 2000: 594; Armstrong and Segars, 2013). Attempts to redress potentially diminished fertility through assisted reproductive technologies are unlikely to be equitably accessible and will involve medical interventions disproportionately borne by women. As Gaard (2010) argues, the rhetoric of "choice" is unjustly used to blame women for fertility problems and to privatize infertility caused by environmental causes through assisted reproduction. As a result of all of these factors, women are likely to bear a disproportionate burden of blame for intergenerational harms caused by endocrine disruptors, and will shoulder more of the work of attempting to remediate these harms.

A feminist ethics should therefore be applied to intergenerational justice (Mackenzie, Rogers, and Dodds, 2013). Such a feminist intergenerational ethics would recognize how we are all interdependent rather than autonomous individuals. An appropriate understanding of embodiment includes the recognition of our interdependence on others (Diprose, 2002), and intergenerational justice requires recognizing that we are embodied and relational, rather than autonomous (Beasley and Bacchi, 2007). However, in doing so we must avoid retrenching unequal patterns of distributing care work (MacGregor, 2006). Exposure to chemicals may produce effects throughout the lifespan and may be passed on to future generations. However, because of patterns of health inequalities across populations, we ought to examine the social structures that lead to health disparities instead of moving further in the direction of assigning individual moral responsibility for health, and particularly, women's disproportionate responsibility for their children's health (Hessler, 2013). There are obstacles in theorizing harm to future persons without relying on conceptions of "normal" 
or "natural" bodies that have been challenged by feminist, queer, and critical disability approaches.

Disability rights activists and scholars have argued that the medical model of disability should be replaced by a social model in which disability is understood as a form of oppression. People with disabilities are "oppressed by society's failure to provide adequately for their needs, not simply on an individual basis but as a consequence of social organization which systematically discriminates against them as a group" (Price and Shildrick, 1998: 227). However, Price and Shildrick (1998) move beyond the social model, to destabilize the normative binary categories of disabled/non-disabled. As they argue, this deconstruction is necessary in order to conceptualize difference as irreducible and multiple and concomitantly render the categories of disability and ability as inherently unstable and porous, because the spectre of one continuously resides in the other. The uncertainty of the effects of endocrine disruptors and the invisibility of some of those effects until attempts to reproduce expose them, illustrate this destabilization and can be understood through a postmodern feminist theory of health. As Einstein and Shildrick (2009) argue, a postmodern feminist account of health must include an understanding of bodies in context, an epistemology of ignorance, ${ }^{1}$ and an openness to the risk of the unknown. Given the (for now) uncertain pathways of endocrine disruption, it is not possible to predict how they will impact individuals in different ways. As the critical disability movement has unsettled binaries between disabled/non-disabled,

\footnotetext{
${ }^{1}$ An epistemology of ignorance recognizes that the complex practices of knowledge production cannot be fully understood, nor can the variety of features account for why something is known. As (Tuana, 2006) argues, epistemologies of ignorance are often integral to resistance movements.
} 
arguing that we are all at least potentially disabled, in the context of endocrine disruption, we see that this potential disability is also intergenerational.

Endocrine disruption has been tied to fears of widespread feminization (Roberts, 2003). Endocrine-disruptors have been described as creating a "sex panic" because of their effects on the sexual differentiation of bodies, but this response has been criticized by the queer ecology movement (Di Chiro, 2010). Although synthetic endocrine disrupters may affect biological variation, they do not create it (Langston 2010: 144); sexual difference is already widely variable and confounds binaries (Hird, 2004). Therefore, environmentalism must not rely on a heteronormative conception of the "healthy body". Instead, we must ask how we can "develop a more proactive (rather than polluted) politics that argues for the integrity, security, and health of bodies, homes, families, and communities without reproducing the eugenics discourse of the “normal/natural”?" (Di Chiro, 2010: 210). The queer ecology response to endocrine disruption demands that we address the potential harms posed by endocrine disruptors such as BFRs and phthalates without relying on sensationalistic appeals to the normal or natural body as being under attack.

\section{Theorizing responsibility to future persons: upholding difference}

A liberal, autonomous individual-based approach forms the basis of many formulations of intergenerational justice, but as feminist critics point out, such an approach fails to take into account the effects of difference (Woolley, 2000; Abbey, 2013). One example of the liberal approach to intergenerational justice is Habermas' (2003) humanist position that we ought not to interfere in the "natural" constitution of 
future human beings. He finds this objectionable because future human beings would not have the same relationship to their own formation. Their genetic make up would be determined, rather than naturally given. This would lead to a conflation between humans and things that Habermas finds unacceptable because it would undermine the freedom of social relationships. Habermas (2003: 14) argues that,

A previously unheard-of relationship arises when a person makes an irreversible decision about the natural traits of another person...the fundamental symmetry of responsibility that exists among free and equal persons is restricted. We have a fundamentally different kind of freedom toward the fate produced through the contingencies of our socialization than we would have toward the prenatal production of our genome.

While Habermas' argument appears to support an ethics of protecting future generations against potential harms caused by exposure to endocrine disruptors, his reliance on a liberal autonomous model of the self is problematic. Although Habermas presumes a separation between "artificial" intervention and "natural" inherited genomes, the potential effects of endocrine disruptors on future generations undermine this distinction. The endocrine-disrupting effects of chemicals disturb conventional conceptions of the body as unified, non-porous, and non-volatile. These effects threaten our understandings of ourselves as discrete individuals. Our genomes are not in fact discretely and individually formed. The way we are formed as individuals cannot be separated from our environment. Feminist theorists challenge Habermas' view of "natural" human genesis and contest his conception of the lifeworld as fundamentally symmetrical and the site of equality and freedom (Johnson, 2004). Although Habermas does not want to allow for control over people, theories of intersectional oppression have taught us that this is already the case (Hooks, 2000). Future human beings will be unable to regard themselves as unaffected by endocrine disruptors. 
Intergenerational justice is not only about responsibility to future persons; it also involves determining what the polity of the future will look like through deciding who will become a future citizen. It is insufficient to attempt to protect future persons in the abstract; we must take difference seriously. Therefore, an ethical framework of intergenerational justice must uphold difference rather than seek to promote particular ideals of bodies and citizens. The feminist, disability rights, and queer ecology responses to endocrine disruptors share a refusal to uphold an ideal body even as they criticize illnesses resulting from chemical exposures. The givenness of any body must be contested, since "the normal body is materialized through a set of reiterative practices that speak to the instability of the singular standard" (Shildrick, 1999: 80).

An intersectional analysis of intergenerational justice is necessary in order to respond ethically and politically to the threats posed by endocrine-disrupting chemicals. Silvers argues that intergenerational justice requires that we refrain from medicalizing difference and emphasize relationships between people and interdependence rather than our current focus on autonomy, with its assumption of a young, usually male, nondisabled status (Silvers, 2000). Therefore, in the final section of this paper we explore several theoretical models by which we can move away from a focus on difference understood in terms of medicalized harms, toward a theorization of difference as a model of positive becoming.

\section{Genealogies of difference: imagining future others}

Reproduction has traditionally been privatized and excluded from the public (political) sphere of life, and rendered largely the responsibility of women. Bryson argues 
that recognizing the ethical and political importance of reproduction produces a different conception of time: "In contrast to the male time of paid production, many describe 'women's time' as cyclical, natural, task-oriented, relational and embedded, the time of reproduction, the family and personal relationships" (Bryson, 2007: 122).

Gardiner (2006) describes our inability to properly consider the needs of future generations as "moral corruption". This failure of ethical imagination is a product of our understanding of time as linear and individual, a conception which Bryson (2007: 127) argues is challenged by reproduction: "At an abstract level, childbirth both generates time for the child that is born and links each mother to the continuing reproduction of the species. As such, it may also challenge her sense of individual time and autonomy and provide a source of temporal understanding that goes beyond linearity". Taking reproduction seriously demands that we rethink time, going beyond the linear time of the individual, to instead consider time in terms of generations.

Irigaray's (1993) work on genealogies can provide a way of understanding our ethical responsibilities as spanning generations. Irigaray recognizes that sexual difference is not biologically fixed or unchanging, and yet serves as the foundation for radical alterity. According to Irigaray, genealogies, the stories we tell about who we are and where we come from, help determine our present values. Although the dominant genealogies in Western culture are currently masculine and focus on the contributions of fathers, a matrilineal reconceptualization of genealogy could recognize the flourishing of sexual difference and the importance of birth in our understanding of time (Irigaray 1993).

Drawing on Hannah Arendt's concept of natality, responsibility to future generations can be grounded in birth as an opening to difference. Arendt (1998: 247) 
asserts that the "miracle that saves the world, the realm of human affairs, from its normal, "natural" ruin is ultimately the fact of natality, in which the faculty of action is ontologically rooted. It is, in other words, the birth of new men and the new beginning, the action they are capable of by virtue of being born". Natality goes beyond biological reproduction to include the development of new future political communities as well. Natality is both natural and social and thus contests the delegation of reproduction to the private sphere of life. It also challenges linear, individual notions of time that undermine an ethics of intergenerational justice. Arendt writes that,

Nature and the cyclical movement into which she forces all living things know neither birth nor death as we understand them. The birth and death of human beings are not simple natural occurrences, but are related to a world in which single individuals, unique, unexchangeable, and unrepeatable entities, appear and from which they depart. Birth and death presuppose a world which is not in constant movement, but whose durability and relative permanence makes appearance and disappearance possible, which existed before any one individual appeared into it and will survive his eventual departure. Without a world into which men are born and from which they die, there would be nothing but changeless eternal recurrence, the deathless everlastingness of the human as of all other animal species (Arendt 1998, 96-97).

Arendt's conception of natality offers a way of understanding our responsibility to future generations without foreclosing on who those future people may be, thereby avoiding the "econormativity" that queer theorists and critical disability theorists criticize. By turning to Arendt, the charge of essentialism can also be avoided since she does not limit natality to women.

As Lisa Guenther (2006) convincingly argues, we can usefully connect Arendt's concept of natality to Emmanuel Levinas' understanding of ethics as responsibility to the Other. Levinas $(2007 ; 1981)$ understands ethics as a responsibility to the other that predates (and postdates) our very existence. According to Levinas, there can be no 
autonomous individual since our very existence is predicated on infinite ethical responsibility to the Other, which we have not chosen but are nevertheless subject to. Following this conception of subjectivity, we can overcome the distinction between synchronic and diachronic justice (intra- and intergenerational), since our ethical obligations are not limited by time or proximity. By following Guenther and connecting Arendt's conception of natality with Levinas' ethics, we can develop an understanding of intergenerational justice that disrupts notions of unified, abstract selfhood and that instead recognizes a responsibility to protect difference across and within generations.

Intergenerational justice is an ethical and political response to threats to our survival. Nevertheless, we must not respond by attempting to protect "the species"; rather, we should strive to protect future individuals who do not yet exist but who will vary widely in their characteristics and needs. As Elizabeth Grosz (2011) argues, the forces of difference come from within species themselves. Darwinian sexual selection aims at the maximization of difference, producing excesses in life (Grosz, 2011, p. 130).

Endocrine-disruptors are widely portrayed as producing "abnormalities" in the sexual differentiation of women and men, resulting in "sex panic" (Roberts 2003). But Grosz (2011: 128-133) explains that attempts to ensure the future of human reproduction by protecting normative ideals of bodies, genders, and sexuality get Darwin wrong by conflating natural and sexual selection, making the same error as the sociobiologists. In responding to endocrine disruptors from an intergenerational justice framework, sex panic and heteronormativity must be avoided. While natural selection regulates sexual difference through reproduction, Grosz (2011: 130) explains that sexual selection is about erotic intensification, inducing "pleasure rather than progeny". She asserts that "Sexual 
selection may be understood as the queering of natural selection, that is, the rendering of any biological norms, ideals of fitness, strange, incalculable, excessive" (Grosz, 2011: 132).

The insight of transcorporeality allows us to recognize the porous nature of bodies and environments (Alaimo, 2008; Alaimo, 2010b; Alaimo, 2010a; Alaimo, 2009), which is essential given the unpredictability of chemical interactions in the environment and the different vulnerabilities of bodies. The interactions between endocrine-disruptors, bodies, and environments will produce a range of effects, which we are only beginning to understand. Ethical responsibility to future generations must be grounded in an openness to change and difference, through which we can develop an understanding of intergenerational justice that disrupts notions of unified, abstract selfhood and that instead recognizes a responsibility to protect difference across and within generations. We need to both attempt to minimize the suffering of future generations, while also welcoming the unknown, that which confounds our expectations, and without attempting to exclude those future persons who do not conform to our existing norms of sexual difference.

Promoting increased capacities for action should be the criterion for intergenerational justice, not ensuring continued conformity with existing categories of life. Such a concept of becoming provides an answer to the queer critiques of "econormativity", since Grosz's conception of sexual difference is not based on any hierarchy of the sexes, but in contending the incommensurability of the male and the female it insists on the plurality of life and its potential possibilities of dispersion. Grosz (2011: 146) upholds the importance of sexual difference, since without "the indeterminable difference between two beings who do not yet exist, who are in the 
process of becoming", there would be nothing but an asexual reproduction of the same. Nevertheless, the biological mixing of two sexes is capable of infinitely multiplying differences. Nature has an unlimited biological capacity for novel generation, according to Grosz, extending into the new and the unforeseeable (Grosz, 2011: 33). Life is the "ever more complex elaboration of difference" (Grosz, 2011: 3). Drawing on Grosz, we ask how can we understand intergenerational justice as a way of holding open future possibilities in order to promote positive becoming, asking "how becomings undo the stabilities of identity, knowledge, location, and being, and how they elaborate new directions and new forces that emerge from these processes of destabilization" (Grosz, 2011: 3). Since it is impossible to know in advance what the difference of the future will look like, imagination is required to respond ethically and politically to the threats to future generations, as well as ongoing witnessing of how difference contributes to the fullness of life. 


\section{Works Cited}

Abbey R Ed. (2013). Feminist Interpretations of John Rawls. University Park, Pa: Penn State University Press.

Alaimo S (2008). Trans-Corporeal Feminisms and the Ethical Space of Nature. In Material Feminisms, ed. Stacy Alaimo and Susan J. Hekman. Indianapolis: Indiana University Press.

_-_-(2009). MCS Matters: Material Agency in the Science and Practices of Environmental Illness. TOPIA: Canadian Journal of Cultural Studies 21: 9-27.

- - (2010a). "The Naked Word: The Trans-Corporeal Ethics of the Protesting Body." Women \& Performance: A Journal of Feminist Theory 20 (1): 15-36. doi:10.1080/07407701003589253.

_-_-(2010b). Bodily Natures: Science, Environment, and the Material Self. Indianapolis: Indiana University Press.

Albert 0 and Jégou B (2014). A Critical Assessment of the Endocrine Susceptibility of the Human Testis to Phthalates from Fetal Life to Adulthood. Human Reproduction Update 20 (2): 231-49. doi:10.1093/humupd/dmt050.

Anstey E H (2009). Contaminating the Hallowed Maternal Body: A Feminist Approach to the Dilemma of Endocrine Disruptors on Maternal and Child Health. Journal of the Association for Research on Mothering 11 (1): 167-79.

Arendt H (1998). The Human Condition. Chicago: University of Chicago Press.

Armstrong A B, and Segars JH. 2013. "Correcting Reproductive Health Disparities in Women: An Opportunity to Improve the Health of Future Generations." Seminars in Reproductive Medicine 31 (5): 313-16. doi:10.1055/s-00331348888.

Beasley C and Bacchi C (2007). "Envisaging a New Politics for an Ethical Future." Feminist Theory 8 (3): 279.

Birke L (2000). Sitting on the Fence: Biology, Feminism and Gender-Bending Environments. Women's Studies International Forum 23 (5): 587-99. doi:10.1016/S0277-5395(00)00127-8.

Bryson V (2007). Gender and the Politics of Time: Feminist Theory and Contemporary Debates. Bristol: Policy.

Cairns K (2013). "Feeding the 'Organic Child': Mothering through Ethical Consumption.” Journal of Consumer Culture 13 (2): 97-118.

Casals-Casas C andDesvergne B (2011). "Endocrine Disruptors: From Endocrine to Metabolic Disruption." Annual Review of Physiology 73 (1): 135-62. doi:10.1146/annurev-physiol-012110-142200.

Cole L W and Foster SR (2001). From the Ground Up: Environmental Racism and the Rise of the Environmental Justice Movement. New York: NYU Press.

Cutter, S L (2006). Hazards Vulnerability and Environmental Justice. Abingdon, Oxon; New York: Earthscan.

Daniels C R (2006). Exposing Men : The Science and Politics of Male Reproduction. Oxford; New York: Oxford University Press.

Di Chiro G (2010). Polluted Politics? Confronting Toxic Discourse, Sex Panic, and Eco-Normativity. In Queer Ecologies: Sex, Nature, Politics, Desire, ed. Catriona 
Mortimer-Sandilands and Bruce Erickson, 199-230. Indianapolis: Indiana University Press.

Diprose R (2002). Corporeal Generosity: On Giving with Nietzsche, Merleau-Ponty, and Levinas. Albany, NY: SUNY Press.

Einstein G and Shildrick M (2009). The Postconventional Body: Retheorising Women's Health. Social Science \& Medicine 69 (2): 293-300. doi:10.1016/j.socscimed.2009.04.027.

Gaard G (2010). Reproductive Technology, or Reproductive Justice?: An Ecofeminist, Environmental Justice Perspective on the Rhetoric of Choice. Ethics \& the Environment 15 (2): 103-29.

Gardiner S M (2006). Protecting Future Generations: Intergenerational BuckPassing, Theoretical Ineptitude and a Brief for a Global Core Precautionary Principle. In Handbook of Intergenerational Justice, ed. Jörg Tremmel, 148-69. Cheltenham, UK ; Northampton, MA: Edward Elgar.

Gee G C and Payne-Sturges DC (2004). Environmental Health Disparities: A Framework Integrating Psychosocial and Environmental Concepts. Environmental Health Perspectives 112 (17): 1645-53. doi:10.1289/ehp.7074.

Grindler N M, Allsworth JE, Macones GA, Kannan K, Roehl KA, and Cooper AR (2015). Persistent Organic Pollutants and Early Menopause in U.S. Women. PLOS ONE 10 (1): e0116057. doi:10.1371/journal.pone.0116057.

Grosz EA (2011). Becoming undone: Darwinian reflections on life, politics, and art. Duke University Press, Durham.

Guenther L (2006). The Gift of the Other: Levinas and the Politics of Reproduction. SUNY Press, Albany.

Guthman J and Mansfield B (2012). The Implications of Environmental Epigenetics A New Direction for Geographic Inquiry on Health, Space, and Nature-Society Relations. Progress in Human Geography, November, 0309132512463258. doi:10.1177/0309132512463258.

Habermas J (2003). The Future of Human Nature. Cambridge: Polity Press.

Hessler K (2013). Epigenetic Inheritance and the Moral Responsibilities of Mothers. Virtual Mentor 15 (9): 767. doi:10.1001/virtualmentor.2013.15.9.stas1-1309.

Hird M J (2004). Naturally Queer. Feminist Theory 5 (1): 85-89. doi:10.1177/1464700104040817.

Hlimi, T, Skinner K, Hanning RM, Martin ID, Tsuji LJS (2012). Traditional food consumption behaviour and concern with environmental contaminants among Cree schoolchildren of the Mushkegowuk territory. Int. J. Circumpolar Health 71. doi:10.3402/ijch.v71i0.17344

Hooks b (2000). Feminist Theory: From Margin to Center. London: Pluto Press. Hoover E, Cook K, Plain R, Sanchez K, Waghiyi V, Miller P, Dufault R, Sislin C, Carpenter DO (2012). Indigenous Peoples of North America: Environmental Exposures and Reproductive Justice. Environmental Health Perspectives. 120, 1645-1649. doi:10.1289/ehp.1205422

Irigaray L (1993). Sexes and Genealogies. New York: Columbia University Press. Johnson P (2004). Irreconcilable Differences? Habermas and Feminism. In Critical Theory After Habermas, ed. Dieter Freundlieb, Wayne Hudson, and John F. Rundell. BRILL. 
Kortenkamp A (2010). Combined Exposures to Anti-Androgenic Chemicals: Steps towards Cumulative Risk Assessment. International Journal of Andrology 33 (2): 463-74.

Kukla R (2008). Measuring Mothering. International Journal of Feminist Approaches to Bioethics 1 (1): 67-90.

Langston N (2010). Toxic Bodies: Hormone Disruptors and the Legacy of DES. New Haven CT: Yale University Press.

Levinas E (1981). Otherwise than Being: Or, Beyond Essence. Trans. Alphonso Lingis. Pittsburgh: Duquesne University Press.

-_-(2007). Totality and Infinity: An Essay on Exteriority. Trans. Alphonso Lingis. Pittsburgh: Duquesne University Press.

Lottrup G (2006). "Possible Impact of Phthalates on Infant Reproductive Health." International Journal of Andrology 29 (1): 172-80.

MacGregor S (2006). Beyond Mothering Earth: Ecological Citizenship and the Politics of Care. Vancouver: UBC Press.

Mackenzie C, Rogers W, and Dodds S, eds. (2013). Vulnerability: New Essays in Ethics and Feminist Philosophy. Oxford; New York: Oxford University Press.

Martino-Andrade AJ (2009). Coadministration of Active Phthalates Results in Disruption of Foetal Testicular Function in Rats. International Journal of Andrology 32 (6): 704-12.

Morales-Suárez-Varela M, Toft G, Jensen M, Ramlau-Hansen C, Kaerlev L, Thulstrup A-M, Llopis-González A, Olsen J, and Bonde J (2011). Parental Occupational Exposure to Endocrine Disrupting Chemicals and Male Genital Malformations: A Study in the Danish National Birth Cohort Study. Environmental Health 10 (1): 3. doi:10.1186/1476-069X-10-3.

Nelson J (2003). Women of Color and the Reproductive Rights Movement. New York: NYU Press.

Peltier M R, Koo H-C, Getahun D, and Menon R (2015). Does Exposure to Flame Retardants Increase the Risk for Preterm Birth? Journal of Reproductive Immunology 107 (February): 20-25. doi:10.1016/j.jri.2014.11.002.

Perera F and Herbstman J (2011). Prenatal Environmental Exposures, Epigenetics, and Disease. Reproductive Toxicology 31 (3): 363-73. doi:10.1016/j.reprotox.2010.12.055.

Price J and Shildrick M (1998). Uncertain Thoughts on the Dis/abled Body. In Vital Signs: Feminist Reconfigurations of the Bio/logical Body, edited by Margrit Shildrick and Janet Price. Edinburgh: Edinburgh University Press.

Rider C V (2010). Cumulative Effects of in Utero Administration of Mixtures of Reproductive Toxicants That Disrupt Common Target Tissues via Diverse Mechanisms of Toxicity. International Journal of Andrology 33 (2): 443-62.

Rissman E F and Adli M (2014). Minireview: Transgenerational Epigenetic Inheritance: Focus on Endocrine Disrupting Compounds. Endocrinology 155 (8): 2770-80. doi:10.1210/en.2014-1123.

Roberts C (2003). Drowning in a Sea of Estrogens: Sex Hormones, Sexual Reproduction and Sex."Sexualities 6 (2): 195-213. doi:10.1177/1363460703006002003. 
Sathyanarayana S, Alcedo G, Saelens BE, Zhou C, Dills RL, Yu J, and Lanphear B (2013). Unexpected Results in a Randomized Dietary Trial to Reduce Phthalate and Bisphenol A Exposures. Journal of Exposure Science and Environmental Epidemiology 23 (4): 378-84. doi:10.1038/jes.2013.9.

Schecter A, Haffner D, Colacino J, Patel K, Päpke O, Opel M, and Birnbaum L (2010). Polybrominated Diphenyl Ethers (PBDEs) and Hexabromocyclodecane (HBCD) in Composite U.S. Food Samples. Environmental Health Perspectives 118 (3): 357-62. doi:10.1289/ehp.0901345.

Scott DN (2009). "Gender-benders": Sex and Law in the Constitution of Polluted Bodies. Fem. Leg. Stud. 17, 241-265. doi:10.1007/s10691-009-9127-4

Scott D N (2010). "Body Polluted: Questions of Scale, Gender and Remedy." Loyola of Los Angeles Law Review 44: 121-56.

Serrano SE, JBraun J, Trasande L, Dills R, and Sathyanarayana S (2014). Phthalates and Diet: A Review of the Food Monitoring and Epidemiology Data. Environmental Health 13 (1): 43-57. doi:10.1186/1476-069X-13-43.

Sharpe R M and DS (2004). How Strong Is the Evidence of a Link between Environmental Chemicals and Adverse Effects on Human Reproductive Health? BMJ : British Medical Journal 328 (7437): 447-51.

Sheldon S (1999). ReConceiving Masculinity: Imagining Men's Reproductive Bodies in Law. Journal of Law and Society 26 (2): 129-49. doi:10.1111/14676478.00119.

Shildrick M (1999). This Body Which Is Not One: Dealing with Differences. Body \& Society 5 (2-3): 77-92.

Silvers A (2000). Aging Fairly: Feminist and Disability Perspectives on Intergenerational Justice. In Mother Time: Women, Aging, and Ethics, ed. Margaret Urban Walker, 203-26. Lanham, Md.: Rowman \& Littlefield.

Small C M, Murray D, Terrell ML, and Marcus M (2011). Reproductive Outcomes among Women Exposed to a Brominated Flame Retardant in Utero. Archives of Environmental \& Occupational Health 66 (4): 201-8. doi:10.1080/19338244.2010.539640.

Stapleton HM, Eagle S, Sjödin A, and Webster TF. 2012. Serum PBDEs in a North Carolina Toddler Cohort: Associations with Handwipes, House Dust, and Socioeconomic Variables. Environmental Health Perspectives 120 (7): 104954. doi:10.1289/ehp.1104802.

Sze J (2007). Noxious New York: The Racial Politics of Urban Health and Environmental Justice. New York: MIT Press.

Trasande L, Attina TM, Sathyanarayana S, Spanier AJ, and Blustein J (2013). Race/Ethnicity-Specific Associations of Urinary Phthalates with Childhood Body Mass in a Nationally Representative Sample. Environmental Health Perspectives 121 (4): 501-6. doi:10.1289/ehp.1205526.

Tuana N (2006). The Speculum of Ignorance: The Women's Health Movement and Epistemologies of Ignorance. Hypatia 21, 1-19. doi:10.1111/j.15272001.2006.tb01110.x

Tyrrell J, Melzer D, Henley W, Galloway TS, and Osborne NJ (2013). Associations between Socioeconomic Status and Environmental Toxicant Concentrations 
in Adults in the USA: NHANES 2001-2010. Environment International 59 (September): 328-35. doi:10.1016/j.envint.2013.06.017.

Vandenberg L N, Colborn T, Hayes TB, Heindel JJ, Jacobs DR, Lee D-H, Shioda T, et al. (2012). Hormones and Endocrine-Disrupting Chemicals: Low-Dose Effects and Nonmonotonic Dose Responses. Endocrine Reviews 33 (3): 378-455. doi:10.1210/er.2011-1050.

Weuve, J, Hauser R, Calafat AM, Missmer SA, and Wise LA (2010). Association of Exposure to Phthalates with Endometriosis and Uterine Leiomyomata: Findings from NHANES, 1999-2004. Environmental Health Perspectives 118 (6): 825-32. doi:10.1289/ehp.0901543.

Wolff MS, Teitelbaum SL, Windham G, Pinney SM, Britton JA, Chelimo C, Godbold J, et al. 2007. Pilot Study of Urinary Biomarkers of Phytoestrogens, Phthalates, and Phenols in Girls. Environmental Health Perspectives 115 (1): 116-21. doi:10.1289/ehp.9488.

Woolley F (2000). Degrees of Connection: A Critique of Rawls's Theory of Mutual Disinterest. Feminist Economics 6 (2): 1-21. doi:10.1080/13545700050076089.

Young I M (2011). Justice and the Politics of Difference. Princeton, N.J.: Princeton University Press.

Zoeller RT, Brown TR, Doan LL, Gore AC, Skakkebaek NE, Soto AM, Woodruff TJ, and Vom Saal FS (2012). Endocrine-Disrupting Chemicals and Public Health Protection: A Statement of Principles from The Endocrine Society. Endocrinology 153 (9): 4097-4110. doi:10.1210/en.2012-1422.

Zota AR, Adamkiewicz G, and Morello-Frosch RA (2010). Are PBDEs an Environmental Equity Concern? Exposure Disparities by Socioeconomic Status. Environ. Sci. Technol. 44 (15): 5691-92. doi:10.1021/es101723d. 